\title{
Evolution of Biochemical, Hematological, Inflammatory and Immunological Markers among Person Living with HIV-1 on ART in Burkina Faso
}

\author{
S. Rokiatou Henry1,2, Yeri Esther Hien ${ }^{2}$, S. Guillaume Sanou ${ }^{3}$, Appollinaire Kima ${ }^{4}$, \\ P. Denise Ilboudo5, Elie Kabre1, Yves Traore ${ }^{2}$
}

\begin{abstract}
${ }^{1}$ Laboratoire National de Santé Publique (LNSP), Boulevard des Tensoba, Ouagadougou, Burkina Faso
${ }^{2}$ Laboratoire de Biochimie et d'Immunologie Appliquée (LABIA) Unité de Formation et de Recherche en Science de la Vie et de la Terre, Université Joseph Ki-Zerbo, Ouagadougou, Burkina Faso

${ }^{3}$ Centre National de Recherche et de Formation sur le Paludisme (CNRFP), Ouagadougou, Burkina Faso

${ }^{4}$ Medecin Referent, Communuty Association ALAVI, Ouagadougou, Burkina Faso

${ }^{5}$ Université de Fada N'Gourma, Fada N'Gourma, Burkina Faso

Email: *yriestherhien@yahoo.fr
\end{abstract}

How to cite this paper: Henry, S.R., Hien, Y.E., Sanou, S.G., Kima, A., Ilboudo, P.D., Kabre, E. and Traore, Y. (2021) Evolution of Biochemical, Hematological, Inflammatory and Immunological Markers among Person Living with HIV-1 on ART in Burkina Faso. Advances in Infectious Diseases, 11, 104-121.

https://doi.org/10.4236/aid.2021.112012

Received: February 18, 2021

Accepted: March 22, 2021

Published: April 13, 2021

Copyright $\odot 2021$ by author(s) and Scientific Research Publishing Inc. This work is licensed under the Creative Commons Attribution International License (CC BY 4.0).

http://creativecommons.org/licenses/by/4.0/ cc) (i) Open Access

\begin{abstract}
In Human immunodeficiency virus infected (HIV+) patients, deregulation of regulatory $\mathrm{T}$ (Treg) cells can be deleterious for the development of an efficient anti-HIV specific immune response with an inappropriate immune activation despite anti-retroviral therapy (ART). In addition, infection and ART have the potential to cause hematological and biochemical abnormalities that can lead to the discontinuation of ART. The aim of this study was to assess hematological, biochemical and immunological abnormalities in HIV+ patients' naïve to ART and 6 months after ART initiation. In a cross-sectional study, $11 \mathrm{HIV}+$ patients and 09 healthy individuals (control group) were voluntarily recruited. At inclusion, blood samples were taken before administration of ART. All hematological, biochemical, immunological parameters and viral load were measured and assessed at inclusion (M0) and three and/or six months later (M3, M6). Higher level of white blood cells and CD4+ T lymphocytes ( $\mathrm{p}=0.032,0.038$ respectively) were observed in HIV+ patients. ART also had significantly effect on the level of red blood cells $(p=0.04)$ and $\mathrm{Hb}$ $(p=0.015)$. The inflammatory markers, erythrocyte sedimentation rate (ESR) and C-reactive protein (CRP) that were significantly increased by HIV infection, tended to decrease for ESR and revert to levels similar to those of control for CRP. Analysis of CD4+CD25+ cells and CD4+Foxp3+CD25+ showed significantly elevated levels of activated form of all CD4+ cells and Treg cells.
\end{abstract}


Interestingly, six months after initiation of ART, the average percentage of $\mathrm{CD} 4+\mathrm{CD} 25+$ was not significantly different from control group ( $\mathrm{p}=0.382$ ). Our study provides information about the evolution of the activated form of all CD4 cells and Treg cells and points out the necessity to monitor hematological and biochemical parameters in order to detect and prevent toxicity, improve the quality of life and reduce the risk of mortality.

\section{Keywords}

Biological Markers, TReg, ART, HIV, Burkina Faso

\section{Introduction}

Human immunodeficiency virus (HIV) is an RNA retrovirus that infects immune cells and uses the host cell transcriptional and translational machineries to proliferate and undermine the health of the host. Infection with HIV is characterized by progressive immunodeficiency, immune activation and depletion of CD4+ cells [1]. This virus causes progressive impairment of the immune system, leading to increased susceptibility to infections, tumors and the fatal condition, called acquired immunodeficiency syndrome (AIDS) [2].

By 2019 there were nearly 38.0 million people globally living with HIV/AIDS, with an increasing trend and a shift towards the younger population [3]. Disease progression in HIV-infected patients can be delayed by treatment with anti-retroviral therapy (ART). It results in diminished viral replication and increased number of CD4+ cells [4]. The treatment of HIV infection is a life-long undertaking, and therapeutic benefit can be limited by the evolution of drug-resistant virus and long-term toxicity resulting in treatment failure. However, the infection remains currently incurable and lifetime treatment is required due to the viral persistence in latent reservoirs that are not accessible to ART and not detectable by the immune system [5] [6]. More so, the patients receiving ART will experience significant side effects. ART is known to be toxic to liver and bone marrow, in several studies the relationship of HIV viruses and anti-retroviral drug effect on several parameters has been reported [7] [8]. Hematological and metabolic abnormalities are frequent among HIV+ infected patients and may be directly attributed to the virus. The abnormalities may be caused by opportunistic infections, neoplasms that cause bone marrow suppression or haemolysis though that can be corrected, prevented and improved by treatment with ART [9].

Regulatory $\mathrm{T}$ (Treg) cells are a subset of CD4+ $\mathrm{T}$ cells that control hyper activation of the immune system due to their suppressive capacity [10]. They are known to modulate the host response to viral infections, but their role in HIV pathogenesis is still controversial and studies on Treg deregulation and function in HIV+ patients have shown dual impacts [11] [12]. The pathogenic role of Tregs in HIV infection is still unclear. Treg-induced suppression can be delete- 
rious for the development of an efficient anti-HIV specific immune response, but it may be also helpful in preventing an inappropriate immune activation [13]. Therefore, high levels of Treg in HIV+ patients are related to reduce immune activation. However, a high level of Treg is related to a high viremia associated with poor immune restoration and persistence of the HIV reservoir [13] [14] [15].

ART remains the best course of action in the management of HIV cases; nevertheless, ART related abnormalities complicate diseases management. These adverse effects during ART sometimes cause the change or suspension of therapy and account for therapy non-adherence by patients [16]. As a result, side effects of ART are a public health concern with an increased number of people living with HIV, and concern an immense importance to health policy makers in Burkina Faso. Unfortunately, data on the side effects of ART on Burkinabe patients are scarce. Therefore, this study sought to assess hematological, inflammatory and biochemical abnormalities in HIV+ patients' naïve to ART and 6 months after ART initiation and the evolution of their immunological responses.

\section{Materials and Methods}

\section{Study population}

All participants were recruited according to a protocol that was presented to the clinical ethics committees for health research of Burkina Faso. The sample analysis was based on a routine clinical anonymized process. Written informed consent was obtained from all the participants, and the study has been done in accordance with good clinical practice. The study was conducted between June 2015 and May 2016 and samples were freshly processed on the day of collection.

Two groups of participants were investigated. The first group consisted of 11 patients infected with HIV-1 HIV+. The inclusion criteria for this group were being infected by HIV-1 only and naïve to ART. The second group consisted of 09 healthy individuals as control group. This group consists of people not infected with HIV and in apparent good health. Patients co-infected with HIV-1 and HIV-2, as well as HIV-1 patients with another infectious disease, were not included in the study.

The positive or negative diagnostic of HIV-1 was obtained by using the national algorithm for HIV-1 diagnosis based on a combination of two simple rapid HIV assays: Determine ${ }^{\mathrm{TM}} \mathrm{HIV}-1 / 2$ (Inverness Medical) and SD Bioline HIV 1/2 3.0 (Standard Diagnostics Inc.). All eligible participants included were at least 18 years of age.

Participants were visited at entry (M0), 3 mouths (M3) and/or 6 mouths (M6) after ART initiation with nucleoside reverse transcriptase inhibitors (NRTIs) and non-nucleoside reverse transcriptase inhibitors (NNRTIs) and measurements were taken at the same time point.

\section{Hematological and biochemical analysis}

The samples consisted of the withdrawing of $5 \mathrm{~mL}$ of venous blood from each patient into an ethylenediaminetetraacetic acid (EDTA) tube for hematological analysis. Citrate anticoagulation tubes were used for erythrocyte sedimentation 
rate (ESR), and non-anticoagulation tubes for biochemical analysis.

Blood samples collected in EDTA tube were analyzed using hematology analyzer PENTRA NEXUS DX (HORIBA) following the manufacturer's instructions. The count of white blood cell count (WBC, $\left.10^{3} / \mathrm{mm}^{3}\right)$, lymphocytes $\left(10^{3} / \mathrm{mm}^{3}\right)$, red blood cell (RBC, $\left.10^{3} / \mathrm{mm}^{3}\right)$, platelets (pLT, $10^{3} / \mathrm{mm}^{3}$ ) and hemoglobin $(\mathrm{Hb}, \mathrm{g} / \mathrm{dl})$ have been done.

ESR was assessed by taking $2 \mathrm{ml}$ of blood, diluted in $0.5 \mathrm{ml}$ of Trisodium Citrate solution using the Westergren pipette that was filled to a zero mark and mounted on a stand with the time adjusted to exactly 1 hour for the red cell to sediment. The column of the sedimented red cells was read at exactly 1 hour and results were reported in $\mathrm{mm} /$ hour.

For the biochemical analysis, serum was separated by centrifugation at $500^{\star} \mathrm{g}$ for 5 minutes ( $\mathrm{min}$ ) and performed on the biochemical analyzer ARCHITECT c4000 (ABBOTT). Alanine transaminase (ALT U/L, normal values 0 - $34 \mathrm{U} / \mathrm{L}$ ), aspartate transaminase (AST U/L, normal values 0 - $31 \mathrm{U} / \mathrm{L}$ ), glycaemia (GLY $\mathrm{mmol} / \mathrm{L}$, normal values $4.10-6.10 \mathrm{mmol} / \mathrm{L}$ ), C-reactive protein (CRP,) and creatinine (Creat $\mu \mathrm{mol} / \mathrm{L}$, normal values $65-120 \mu \mathrm{mol} / \mathrm{L}$ for men and $50-100 \mu \mathrm{mol}$ for women), were detected from the serum samples.

Flow Cytometry Analysis, gating strategy and staining method

Measurements of CD4 counts were performed in HIV+ patients and controls at the three time points (M0, M3, M6). Absolute count of CD4+ cells was done using FACS Calibur flow cytometry with CellQuest software (BD Biosciences, USA). Interested lymphocytes subsets were determined by 3-color flow cytometry according to a Single-Platform Absolute Count Methodology. Determination of lymphocyte subsets and preparation of cells for flow cytometry was performed as described below.

Briefly, $100 \mu \mathrm{L}$ of whole blood were stained with various combinations of optimal staining concentrations of fluoroisothiocyanate (FITC) conjugated-CD3 or $\mathrm{CD} 25$, phycoerythrin $(\mathrm{pE}$ ) conjugated-FoxP3, and $\mathrm{PE} / \mathrm{Dy} 647$ conjugated-CD4 or CD45. All antibodies were from BD Biosciences, CA, USA and the incubation was for $15 \mathrm{~min}$ at room temperature in the dark. After staining, $2 \mathrm{ml}$ of lysing solution were added in order to lyse erythrocytes for $10 \mathrm{~min}$ at room temperature in the dark. The mixture was then centrifuged $5 \mathrm{~min}$ at $540^{\star} \mathrm{g}$ at room temperature and cells were washed two times with $2 \mathrm{ml}$ of phosphate-buffered saline (pBS) at room temperature. After washes, the cells were re-suspended in $1 \mathrm{ml}$ of PBS and analyzed.

The antibodies and fluorochromes used for lymphocytes subpopulations analysis are shown in Table 1. The relative numbers (percentage gated) of immune subsets were determined using Flow-Count method (CYFLOW).

Table 1. Antibodies and fluorochromes.

\begin{tabular}{cc}
\hline & Antibodies-fluorochromes \\
\hline T Cells & CD3-FITC/CD45-PE-647 \\
TReg Cells & CD4 PE Dy647/CD25-FITC/FOXP3-PE \\
\hline
\end{tabular}


A no-labelled negative control was used for each sample. Forward and side scatter histogram was used to define the lymphocytes populations. CD4 cells and CD45 cells were gated. Then, the expression of CD25 on CD4+ cells (CD25/CD4+) cells, FOXP3 on CD4 (FOXP3/CD4), FOXP3 on CD25 (FOXP3/CD25) was determined. The results of $\mathrm{CD} 25+$ and FOXP3+ cells were expressed as percentage of CD4+ cells. Data were collected using a Partec CYFLOW cytometer and analyzed with the FLOMAX software.

For intracellular staining, Anti-FoxP3 antibody was used to identify and enumerate $\mathrm{CD} 4+\mathrm{CD} 25+\mathrm{FoxP} 3+$ regulatory $\mathrm{T}$ cells. To achieve this, $100 \mu \mathrm{L}$ of the whole blood was added in $1 \mathrm{~mL}$ of cold, freshly prepared Fixation/ Permeabilization Solution. The mix was incubated for 20 minutes in the dark in room temperature. Cells were then washed by adding $2 \mathrm{~mL}$ of cold buffer and centrifuged at $250^{\star} \mathrm{g}$ for 5 minutes at $4^{\circ} \mathrm{C}$. The supernatant was completely aspirated and cells were fixed by adding $2 \mathrm{ml}$ of $1 \mathrm{X}$ Human FoxP3 Buffer A for 10 minutes at room temperature in dark. The mix was centrifuged at $500^{\star} \mathrm{g}$ for $5 \mathrm{~min}$ to remove fixative. Cells were washed with $2 \mathrm{ml}$ of BD Pharmamingen Stain Buffer, and centrifuged $500^{*} \mathrm{~g}$ for 5 minutes to remove the buffer.

For cell permeabilization, the pellet was gently re-suspended in residual volume of BD Pharmingen Stain Buffer and $0.5 \mathrm{ml}$ of permeabilization solution were added. The mix was vortexed and incubated for 30 minutes at room temperature protected from light. After incubation, cells were washed two-time with $2 \mathrm{ml}$ of BD Pharmingen Stain Buffer and centrifuged at $500^{\star} \mathrm{g}$ during $5 \mathrm{~min}$ at room temperature to remove buffer. Conjugated FoxP3 antibody at appropriate concentrations was then added to re-suspend the pellet that was gently shaked and incubated for $30 \mathrm{~min}$ in the dark at room temperature. Cells were washed once more and re-suspended in wash buffer and analyzed immediately.

\section{Viral load measurements (VL)}

HIV-RNA viral load was measured in HIV-infected patients at M0 and M6. The COBAS ${ }^{\circledR}$ AmpliPrep /COBAS ${ }^{\circledR}$ TaqMan ${ }^{\circledR}$ HIV-1 Test was used for automated viral load analysis. The test can quantitate HIV-1 RNA over the range of $48-10,000,000$ copies/mL. One copy of HIV-1 RNA is equivalent to $1.7 \pm 0.1$ International Units (IU) based on the WHO 1st International Standard for HIV-1 RNA for Nucleic Acid-Based Techniques (NAT) (NIBSC 97/656) [17].

\section{Specimen Preparation}

The COBAS ${ }^{\circledR}$ AmpliPrep/COBAS $^{\circledR}$ TaqMan $^{\circledR}$ HIV-1 Test utilizes automated specimen preparation on the COBAS ${ }^{\circledR}$ AmpliPrep Instrument by a generic silica-based capture technique. Extraction, amplification, and detection for plasma specimens were made followed the Cobas Amplicor manufacturer's standard preparation guidelines. Briefly, $850 \mu \mathrm{l}$ of plasma specimen was lysed by incubation at elevated temperature with a protease and chaotropic lysis/binding buffer that releases nucleic acids and protects the released HIV-1 RNA from RNases in plasma. Protease and a known number of HIV-1 QS Armored RNA molecules are introduced into each specimen along with the lysis reagent and magnetic glass particles. Subsequently, the mixture is incubated and the HIV-1 RNA and 
HIV-1 QS RNA are bound to the surface of the magnetic glass particles. Unbound substances, such as salts, proteins and other cellular impurities, are removed by washing the magnetic glass particles. After separating the magnetic glass particles and completing the washing steps, the adsorbed nucleic acids are eluted at elevated temperature with an aqueous solution [17].

Reverse Transcription and PCR Amplification

The reverse transcription and PCR amplification reaction are performed with the thermostable recombinant enzyme Thermus specie DNA Polymerase (Z05). In the presence of manganese $\left(\mathrm{Mn}^{2+}\right)$ and under the appropriate buffer conditions, Z05 has both reverse transcriptase and DNA polymerase activity. This allows both reverse transcription and PCR amplification to occur together with real-time detection of the amplicon. Processed specimens are added to the amplification mixture in amplification tubes (K-tubes) in which both reverse transcription and PCR amplification occur. The reaction mixture is heated to allow a down-stream primer to anneal specifically to the HIV-1 target RNA and to the HIV-1 QS RNA. In the presence of $\mathrm{Mn}^{2+}$ and excess deoxynucleotide triphosphates (dNTPs), including deoxyadenosine, deoxyguanosine, deoxycytidine, deoxyuridine and deoxythymidine triphosphates, Z05 polymerase extends the annealed primers forming a DNA strand complementary to the RNA target [17].

Statistical analysis and data management

Statistical analyses were carried out using the GraphPad Prism statistical package software version 6.00 for Windows (GraphPad Software, La Jolla California USA). Mann-Whitney test was performed to compare cell populations and biochemical markers between healthy individuals (control) and HIV-1+ individuals and to assess differences for non-normally distributed continuous variables. The data are represented as the median \pm interquartile range (IQR) except for lymphocytes sub-populations data. All HIV-1 RNA levels in plasma specimens were transformed to $\log 10$ values. Median viral load measurements and interquartile range were calculated for each specimen and time point. Differences were considered significant for $\mathrm{p}$-values $\leq 0.05$.

\section{Ethics consideration}

The study protocol was presented to the Ethics Committee of health science in Burkina Faso and the study was conducted according to the Declaration of Helsinki. All participants gave written informed consent to take part in this study after having read the study information sheet and having any questions answered. The privacy rights of human subjects were observed at all times.

\section{Results}

\section{Patient's characteristic at inclusion}

A total of 20 subjects, women and men, with an age range of 21 to 52 years and a median age of 30 years (mean age 33) were enrolled in the study. Most participants were city dwellers living in Ouagadougou. Among these 20 persons, 11 were HIV+ individuals and 9 healthy individuals who were not infected by HIV and considered as a control group. HIV+ individuals were recruited at the 
time of diagnosis just before starting antiretroviral treatment.

Control patients age was ranged from 21 to 31 years with an average of $26.2 \pm$ 2.6 years and HIV+ patients' age was from 25 to 52 years with an average of 32.0 \pm 7.8. Analysis of patient gender shows that $33 \%$ were women in control patients, while $82 \%$ were women in HIV+ patients (Table 2). All controls participants claimed to be in good health and denied any immediate, acute medical issues. The participant's occupation, education and past medical history were neither investigated nor documented.

Analysis of whole blood leukocyte count showed a significant difference between control patients and HIV+ patients before starting ART $(p=0.002)$. The absolute lymphocytes cells $(\mathrm{p}=0.048)$ and CD4 T cell $(\mathrm{p}<0.0001)$ numbers at sampling were greatly and significantly lower in HIV+ individuals in comparison to the healthy individuals. Analysis of RBC and hemoglobin level also showed a significantly lower value in HIV+ patients $(p=0.0002$ and $p=0.0004$ respectively). However, we did not find a significant difference in the platelets count between the two populations.

Biochemical parameters analysis at baseline has shown a significant difference between controls and HIV+ subjects for ALT $(p=0.024)$, however there is no difference in the level of AST ( $p=0.87$ ). Serum creatinine, which is one of biomarkers for renal disorders diagnosis, shown a rate of $78.00 \mu \mathrm{mol} / 1$ [65.50 88.00] in HIV+ patients versus $68.40 \mu \mathrm{mol} / 1$ [57.15 - 73.50] in control patients ( $\mathrm{p}$ $=0.06)$.

Inflammatory markers analysis showed significantly higher inflammation status among HIV patients compared with the control group. All the inflammation parameters we analyzed were higher in $\mathrm{HIV}+$ patients than in the control group. We found the greatest differences for ESR 6.0 [4.0 - 9.0] in the control group versus 27.0 [22.8 - 34.0] for HIV patients, $\mathrm{p}<0.0001$. CRP was also significantly increased in HIV+ patients in comparison with non-infected group with respectively $1.4[0.8-2.0]$ and $2.7[1.2-3.5], \mathrm{p}=0.026$ (Table 3 ).

Table 2. Sociodemographic characteristics of HIV+-infected and healthy individuals enrolled for the study.

\begin{tabular}{|c|c|c|c|}
\hline & & Frequency or median value & Proportion (\%) \\
\hline \multirow{5}{*}{ Control } & \multirow{4}{*}{$\begin{array}{l}\text { Male } \\
\text { Female }\end{array}$} & Frequency & $\%$ \\
\hline & & 6.0 & 67.0 \\
\hline & & 3.0 & 33.0 \\
\hline & & Median [Q1 - Q3] & \\
\hline & Age (years) & $26.0[25.5-27.5]$ & \\
\hline \multirow{4}{*}{ HIV+ Patients } & \multirow{3}{*}{$\begin{array}{l}\text { Male } \\
\text { Female }\end{array}$} & 2.0 & 18.2 \\
\hline & & 9.0 & 81.8 \\
\hline & & Median [Q1 - Q3] & \\
\hline & Age (years) & $29.0[27.0-36.0]$ & \\
\hline
\end{tabular}


Table 3. Baseline characteristics of HIV+-infected and healthy individuals enrolled for the study at sampling.

\begin{tabular}{|c|c|c|c|}
\hline & $\begin{array}{c}\text { Control } \\
\text { Median [Q1 - Q3] }\end{array}$ & $\begin{array}{c}\text { HIV Patient } \\
\text { Median [Q1 - Q3] }\end{array}$ & $\begin{array}{l}\text { Control vs HIV } \\
\text { Patient p-value }\end{array}$ \\
\hline $\mathrm{N}$ & 9 & 11 & - \\
\hline WBCs $\left(10^{3}\right.$ cells $\left./ \mu \mathrm{l}\right)$ & $4.4[2.8-4.7]$ & $3.0[2.1-3.8]$ & $0.002^{\star}$ \\
\hline Lymphocytes $\left(10^{3}\right.$ cells $\left./ \mu \mathrm{l}\right)$ & $1.8[1.3-2.5]$ & $1.4[1.0-1.9]$ & $0.048^{*}$ \\
\hline CD4 (cells count/ $\mu \mathrm{l})$ & $864.0[623.0-1153.0]$ & $294.0[124.3-418.5]$ & $<0.0001^{*}$ \\
\hline RBCs (106 cells $/ \mu \mathrm{l})$ & $5.2[4.8-5.4]$ & $3.6[3.0-4.3]$ & $0.0002^{*}$ \\
\hline $\mathrm{Hb}(\mathrm{g} / \mathrm{dl})$ & $14.8[13.3-15.8]$ & $9.8[8.9-11.3]$ & $0.0004^{*}$ \\
\hline Platelets $\left(10^{3}\right.$ cells $\left./ \mu \mathrm{l}\right)$ & $234.0[192.5-299.5]$ & $228.0[162.0-277.0]$ & 0.65 \\
\hline ESR & $6.0[4.0-9.0]$ & $27.0[22.8-34.0]$ & $<0.0001^{*}$ \\
\hline CRP & $1.4[0.8-2.0]$ & $2.7[1.2-3.5]$ & $0.026^{*}$ \\
\hline GLY (mmol/l) & $4.1[3.6-4.7]$ & $4.19[3.6-14.9]$ & 0.66 \\
\hline Creat $(\mu \mathrm{mol} / \mathrm{l})$ & $68.40[57.15-73.50]$ & $78.00[65.50-88.00]$ & 0.06 \\
\hline AST (UI/L) & $25[19.5-27.5]$ & $25[14-37]$ & 0.87 \\
\hline $\operatorname{ALT}(\mathrm{UI} / \mathrm{L})$ & $14[11.25-18]$ & $22[16-30]$ & $0.024^{*}$ \\
\hline
\end{tabular}

${ }^{*} \mathrm{p}<0.05, \mathrm{Q} 1$ : quartile 1, Q3: quartile 3, WBCs $=$ White Blood Cells, RBCs $=$ Red Blood Cells, Hb = Hemoglobin, ESR = Erythrocyte Sedimentation Rate, $\mathrm{CRP}=\mathrm{C}$-reactive protein, $\mathrm{GLY}=$ glycaemia, Creat $=$ creatinine, $\mathrm{AST}=\mathrm{ASpartate}$ Transaminase, $\mathrm{ALT}=$ ALanine Transaminase .

\section{Analysis of hematological and biochemical parameters in HIV patients after ART initiation}

Six months after starting ART, HIV patients had significantly higher level of WBCs and CD4+ T lymphocytes ( $\mathrm{p}=0.033$ and 0.038 respectively) in comparison with the level at inclusion. ART also significantly increased the number of RBCs $(p=0.04)$ and $\mathrm{Hb}(\mathrm{p}=0.015)$. In contrast, platelet had modestly higher level after six mouth of ART (Table 4). Comparison of hematological parameters in HIV patients six months after ART initiation with control individuals showed that there is no difference between the two groups for the level of leukocytes and total lymphocytes even if the CD4 level remains low compared to control group (Table 5).

Analysis of biochemical parameters after six months of ART, showed that the level of ALT was at $23 \mathrm{U} / \mathrm{L}$ [19.0 - 35.5] at M6 compared to a rate of $22 \mathrm{U} / \mathrm{L}$ [16.0 - 30.0] found at M0. Comparison of ALT of HIV+ patients at M6 versus controls group showed significant elevated levels of ALT even after ART, 14 U/L [11.25 18] for control and $23 \mathrm{U} / \mathrm{L}$ [19 - 35.5] for HIV+ patients ( $p<0.001)$. However, there was no significant difference in the serum levels for AST (Table 5). Analysis of creatinine level showed that the rate in HIV+ patients was at $78.00 \mu \mathrm{mol} / \mathrm{l}$ [65.50 - 88.00] at M0. This value decreased to 63.40 [58.35 - 72.31] after 6 months of ART (Table 3). 
Table 4. Evolution of hematological and biochemical parameters in HIV patients during the different times points.

\begin{tabular}{|c|c|c|c|c|}
\hline & $\begin{array}{l}\text { HIV Patient M0 } \\
\text { Median [Q1 - Q3] }\end{array}$ & $\begin{array}{l}\text { HIV Patient M3 } \\
\text { Median [Q1 - Q3] }\end{array}$ & $\begin{array}{l}\text { HIV Patient M6 } \\
\text { Median [Q1 - Q3] }\end{array}$ & $\begin{array}{l}\text { M0 vs M6 } \\
\text { HIV Patient } \\
\text { p-value }\end{array}$ \\
\hline $\mathrm{N}$ & 11 & 9 & 9 & - \\
\hline WBCs $\left(10^{3}\right.$ cells/ul $)$ & $3.0[2.1-3.8]$ & $3.7[3.2-4.3]$ & $4.1[3.0-5.4]$ & $0.033^{*}$ \\
\hline $\begin{array}{l}\text { Lymphocytes } \\
\left(10^{3} \text { cells/ul }\right)\end{array}$ & $1.4[1.0-1.9]$ & $1.8[1.3-2.1]$ & $1.8[1.3-2.2]$ & 0.16 \\
\hline CD4 (cells count $/ \mu \mathrm{l})$ & $294.0[124.3-418.5]$ & $450.0[395.5-530.5]$ & $458.0[401.5-543.8]$ & $0.038^{*}$ \\
\hline RBC $\left(10^{6}\right.$ cells/ul $)$ & $3.6[3.0-4.3]$ & $4.1[3.2-4.3]$ & $4.2[3.9-4.5]$ & $0.04^{*}$ \\
\hline $\mathrm{Hb}(\mathrm{g} / \mathrm{dl})$ & $9.8[8.9-11.3]$ & $12.2[11.7-12.4]$ & $12.1[11.7-12.5]$ & $0.015^{*}$ \\
\hline Platelets $\left(10^{3}\right.$ cells $\left./ \mu \mathrm{l}\right)$ & $228.0[162.0-277.0]$ & $235.0[165.0-258.0]$ & $235.0[198.0-350.0]$ & 0.65 \\
\hline ESR & $27.0[22.8-34.0]$ & $28.0[19.0-38.0]$ & $20.0[14.0-35.0]$ & 0.24 \\
\hline CRP & $2.7[1.3-3.7]$ & $1.5[1.3-2.3]$ & $1.13[1.3-3.7]$ & $0.033^{*}$ \\
\hline $\mathrm{GLY}(\mathrm{mmol} / \mathrm{l})$ & $4.19[3.61-4.9]$ & $4.47[3.98-5.24]$ & $4.69[4.56-5.26]$ & 0.099 \\
\hline Creat $(\mu \mathrm{mol} / \mathrm{l})$ & $78.00[65.50-88.00]$ & $65.45[57.85-76.39]$ & $63.40[58.35-72.31]$ & 0.094 \\
\hline $\operatorname{AST}(\mathrm{U} / \mathrm{L})$ & $25.0[14.0-37.0]$ & $24.5[16.75-36.25]$ & $27.00[22.50-33.50]$ & 0.52 \\
\hline $\operatorname{ALT}(\mathrm{U} / \mathrm{L})$ & $22.0[16.0-30.0]$ & $20.0[13.75-29.50]$ & $23.0[19.0-35.5]$ & 0.42 \\
\hline
\end{tabular}

${ }^{*} \mathrm{p}<0.05, \mathrm{Q} 1$ : quartile 1, Q3: quartile 3, WBCs = White Blood Cells, RBCs $=$ Red Blood Cells, Hb $=\mathrm{He}-$ moglobin, ESR = Erythrocyte Sedimentation Rate, $\mathrm{CRP}=\mathrm{C}$-reactive protein, GLY = glycaemia, Creat = creatinine, AST $=$ ASpartate Transaminase, ALT $=$ ALanine Transaminase

Table 5. Comparison of hematological and biochemical parameters in HIV patients six months after ART initiation compared with control individuals.

\begin{tabular}{|c|c|c|c|}
\hline & $\begin{array}{c}\text { Control } \\
\text { Median [Q1 - Q3] }\end{array}$ & $\begin{array}{l}\text { HIV Patient M6 } \\
\text { Median [Q1 - Q3] }\end{array}$ & $\begin{array}{c}\text { Control vs HIV Patient } \\
\text { M6 (p-value) }\end{array}$ \\
\hline $\mathrm{N}$ & 9 & 9 & - \\
\hline WBCs $\left(10^{3}\right.$ cells/ul $)$ & $4.4[2.8-4.7]$ & $4.1[3.0-5.4]$ & 0.56 \\
\hline $\begin{array}{l}\text { Lymphocytes } \\
\left(10^{3} \text { cells/ul }\right)\end{array}$ & $1.8[1.3-2.5]$ & $1.8[1.3-2.2]$ & 0.65 \\
\hline CD4 (cells count/ $\mu \mathrm{l})$ & $864.0[623.0-1153.0]$ & $458.0[401.5-543.8]$ & $0.0016^{*}$ \\
\hline RBCs $\left(10^{6}\right.$ cells $\left./ \mu \mathrm{l}\right)$ & $5.2[4.8-5.4]$ & $4.2[3.9-4.5]$ & $0.0025^{*}$ \\
\hline $\mathrm{Hb}(\mathrm{g} / \mathrm{dl})$ & $14.8[13.3-15.8]$ & $12.1[11.7-12.5]$ & $0.0079^{*}$ \\
\hline Platelets $\left(10^{3}\right.$ cells $\left./ \mu \mathrm{l}\right)$ & 234.0 [192.5 - 299.5] & $235.0[198.0-350.0]$ & 0.68 \\
\hline ESR & $6.0[4.0-9.0]$ & $20.0[14.0-35.0]$ & $0.0002^{*}$ \\
\hline CRP & $1.4[0.8-2.0]$ & $1.13[1.3-3.7]$ & 0.91 \\
\hline GLY (mmol/l) & $4.1[3.6-4.7]$ & $4.69[4.56-5.26]$ & $0.035^{*}$ \\
\hline Creat $(\mu \mathrm{mol} / \mathrm{l})$ & $68.40[57.15-73.50]$ & $63.40[58.35-72.31]$ & 0.91 \\
\hline AST (U/L) & $25[19.5-27.5]$ & $27.00[22.50-33.50]$ & 0.33 \\
\hline $\operatorname{ALT}(\mathrm{U} / \mathrm{L})$ & $14[11.25-18.0]$ & $23[19.0-35.5]$ & $0.001^{\star}$ \\
\hline
\end{tabular}

${ }^{*} \mathrm{p}<0.05, \mathrm{Q} 1$ : quartile 1, Q3: quartile 3, WBCs = White Blood Cells, RBCs = Red Blood Cells, Hb $=\mathrm{He}-$ moglobin, ESR = Erythrocyte Sedimentation Rate, CRP = C-reactive protein, GLY = glycaemia, Creat $=$ creatinine, AST $=$ ASpartate Transaminase, ALT $=$ ALanine Transaminase 


\section{Inflammatory Markers in HIV patients after ART}

The inflammatory markers, ESR and CRP, that were significantly increased by HIV infection tended to decrease for ESR and revert to levels similar to those of uninfected controls for CRP. In fact, ESR level that was at 27.0 [22.8 - 34.0] for HIV+ patients' at inclusion, decreased at 20.0 [14.0 - 35.0] after 6 months of ART (Table 4). CRP level also that was at 2.7 [1.2 - 3.5] $\mu \mathrm{mol} / \mathrm{l}$ for HIV+ patients decreased at 1.13 [1.3 - 3.7] after 6 months of ART. CRP level at M6 was similar to control group with CRP level at $1.4[0.8-2.0](\mathrm{p}=0.9090)($ Table 5).

Evolution of CD4 count and viral load during patient's monitoring

HIV+ individuals were recruited before starting antiretroviral treatment and TCD4 lymphocyte count increased upon initiation of ART. The CD4 count, which was at 208 cells $/ \mathrm{ml}(23-368$ cells $/ \mathrm{ml})$ at M0 rose 458 cells $/ \mathrm{ml}(401.5$ 543.8 cells $/ \mathrm{ml}$ ) at M6; $\mathrm{p}<0.0016$ (Table 5). Viral load analysis before ART showed a median of plasma viral load at 4.2 [3.2 - 5.4] copies $/ \mathrm{ml}$. After 6 mouths of ART, viral load median decreased from 4.2 HIV-RNA $\log 10$ copies $/ \mathrm{ml}$ at M0, to $2.5 \mathrm{HIV}$-RNA $\log 10$ copies $/ \mathrm{ml}$. We also noticed that $36.4 \%$ of patients had viral load undetectable after 6 months of ART compared to $20.0 \%$ at inclusion (Table 6).

Analysis of lymphocytes sub-populations in HIV patients compared with control individuals after ART

To determine immune activation in HIV+ patients, CD4+ cells expressing $\mathrm{CD} 25+$ were measured in HIV+ patients and control group at inclusion and 6 months after ART. We noticed that the average percentage of CD4+CD25+ in HIV patients at initiation of ART (M0) was higher than controls. Indeed the average percentage of $\mathrm{CD} 4+\mathrm{CD} 25+$ of control group was at $4.51 \pm 1.07$ compared to M0 Patients with the percentage of the subpopulation at $13.02 \pm 1.89$ ( $\mathrm{p}=$ 0.0005). Six months after initiation of ART, average percentage of CD4+CD25+ was at $6.02 \pm 1.65$ which was not significantly different from control group ( $\mathrm{p}=$ 0.38 ) as shown in Table 7. Analysis of Treg subpopulation and their activated form did not show a difference between HIV+ patient and control group.

Table 6. Evolution of viral load in HIV patients six months after ART initiation.

\begin{tabular}{cccc}
\hline Viral load & $\mathrm{M} 0$ & $\mathrm{M} 3$ & $\mathrm{M} 6$ \\
$(\log 10$ copies/ml $)$ & $\mathrm{N}(\%)$ & $\mathrm{N}(\%)$ & $\mathrm{N}(\%)$ \\
\hline Median $[\mathrm{Q} 1-\mathrm{Q} 3]$ & $4.2[3.2-5.4]$ & $3.7[2.3-4.4]$ & $2.5[1.7-5.2]$ \\
Undetectable & $2(20.0)$ & $2(18.2)$ & $4(36.4)$ \\
Total & 10 & 11 & 11 \\
\hline
\end{tabular}

Table 7. Proportions of TCD4+/CD25+/CD25+FOXP3+ cells.

\begin{tabular}{cccccccccc}
\hline & \multicolumn{3}{c}{$\mathrm{CD} 4+\mathrm{CD} 25+(\%)$} & \multicolumn{3}{c}{ CD4+ FOXP3+ (\%) } & \multicolumn{3}{c}{ CD4+ FOXP3+CD25+ (\%) } \\
\cline { 2 - 11 } & Control & M0 & M6 & Control & M0 & M6 & Control & M0 & M6 \\
\hline Mean \pm SEM & $4.51 \pm 1.06$ & $13.02 \pm 1.89$ & $6.02 \pm 1.65$ & $11.79 \pm 3.46$ & $5.99 \pm 2.88$ & $14.79 \pm 5.63$ & $7.42 \pm 2.22$ & $15.45 \pm 7.82$ & $10.27 \pm 5.36$ \\
\hline
\end{tabular}




\section{Discussion}

An HIV infection is still a major public health problem especially in developing countries. This infection affects the entire society with an impact in the socio-economic status of individuals, families and communities [18]. ART has helped in suppressing human immunodeficiency viral replication to undetectable levels which have considerably improved the prognosis of this infection by repairing immune system and regulating opportunistic infections [19]. However, the treatment exhibited some side effects, notably the hematological and biochemical abnormalities observed in the patients under treatment. In this study, we sought to assess the evolution of hematological, inflammatory and biochemical parameters in HIV+ patients' naïve to ART and 6 months after ART initiation as well as the evolution of their immunological responses after ART. The main activities were the monitoring of biochemical, hematological, virological and immunological parameters in HIV positive patients under ART in Ouagadougou (Burkina Faso).

The study has been conducted between June 2015 and April 2016 in Ouagadougou (Burkina Faso). The majority of the HIV patients were women (82\%). These women are aged below 40 years; this is keeping with the international's estimates for Burkina Faso [3] showing that in sub-Saharan Africa, five in six new infections among adolescents aged $15-19$ years are among girls. After inclusion in the study, all patients received ART consisting of nucleoside reverse transcriptase inhibitors (NRTIs) and non-nucleoside reverse transcriptase inhibitors (NNRTI), as mentioned in the national guidelines and WHO recommendation for HIV patients monitoring [20].

Anemia is a common hematological abnormality in HIV+ patients and has been shown to predict disease progression and mortality [21] [22]. But until now, the exact mechanism by which HIV in vivo alters the microenvironment in the bone marrow to inhibit hematopoiesis and directly lead to decreased blood cells remains unclear. In this study, we observed an overall effect of ART on hematological parameters in HIV+ patients. After 6 months of ART, patient had shown a significant increase in $\mathrm{Hb}$ value $(\mathrm{p}=0.015)$. This is in line with the works of Odunukwe et al. and Ebonyi et al. who noted an increase in hemoglobin and RBC in patients on ART [23] [24] [25]. We also observed a significant increase of total Leukocyte count, T CD4 lymphocytes. These data are consistent with the work of Odunukwe et al. (2005), Enawgaw and al. (2014). Odunukwe et al. (2005) found a significant increase in total leukocyte in addition to $\mathrm{Hb}$ count after ART initiation. On contrary, Enawgaw and al. found a significant increase in $\mathrm{Hb}$ level and $\mathrm{T} \mathrm{CD} 4+$ lymphocytes without significant increase in leukocyte count [9] [23]. Some drugs such as Zidovudine, a known reverse transcriptase drug has been implicated as an inducer of cytopenias in HIV patients [26]. But, in our study, we did not observe cytopenia after ART initiation. This may be because, in Burkina Faso, the first line of ART includes a combination of Non-Nucleoside Reverse Transcriptase Inhibitors (NNRTI's) and Nucleoside Reverse Transcriptase Inhibitors (NRTI's). Thus treatment, is a 
combined of two Nucleoside Reverse Transcriptase Inhibitors (NRTI's) and Non-Nucleoside Reverse Transcriptase. Another factors such as the study population, socio-demographic characteristics and the design methods employed may account for the decrease in cytopenias after ART initiation as show in other studies [27].

In patients infected with HIV, liver dysfunction is the most common cause of death unrelated to AIDS, accounting for $14 \%$ - $18 \%$ of all deaths. Almost half of the deaths in hospitalized HIV-infected patients on ART have been attributed to liver dysfunction [28] [29]. Nevirapin has been reported as eosinophilia, granulopenia, jaundice and increased enzymes associated to liver function abnormality [30]. We then analyzed biochemical abnormalities of liver function such as elevated levels of liver enzymes involved in breakdown of amino acids, ALT and AST. Theses enzymes reflect liver cell injury and indicate liver disease [31]. In this study, we recorded significant elevated levels $(\mathrm{p}<0.001)$ of ALT after six months of ART even if value is included in the normal range. However, there was no significant difference in the serum levels for AST. Some factors that can explain abnormalities of liver enzyme in HIV patients include opportunistic infections, AIDS related neoplasms, concomitant infection with chronic hepatitis $\mathrm{C}$ virus, chronic hepatitis $\mathrm{B}$ virus, alcohol abuse, and nonalcoholic fatty liver disease [32] [33]. In addition, ART is also a major contributing factor to liver disease. The possible explanation to the elevated levels of ALT after ART in our study could be due to the type of ART drugs that may cause direct mitochondrial toxicity of the liver as well as other organs leading to liver failure and lactic acidosis [34] or the presence of other infection [33]. Antiretroviral drug-related liver injury is defined by elevations in liver enzymes in patient serum; with ALT characteristically greater than AST. It is one of the greatest causes of treatment discontinuation in $\mathrm{HIV}$-infected patients. Its prevention and management are therefore very important among HIV-infected patients who are to be placed on ART [30] [35].

Metabolism and excretion of waste products comprising drug metabolites are one of the major roles of the kidney and the ability of the kidneys to function appropriately is impaired by HIV infection and ART therapy. Renal failure usually manifests as proximal tubular injury with related reduction in glomerular filtration and patients often develop glycosuria, increased serum creatinine and low serum phosphate tubular proteinuria [36]. ART drug, Tenofovir, a known Nucleotide Reverse Transcriptase Inhibitor (NRTI) drug has been implicated in the accumulation of those metabolites in the proximal renal tubule through the activity of kidney-specific organic anion transporters [7] [37] [38]. Through our results, we found that serum creatinine which is one of biomarkers for diagnosing renal disorders were not significantly elevated after ART, in opposition of that was found by Alfano et al. 2019 [37]. Only, the rate of the glycaemia test showed that HIV positive patients have values that are significantly ( $\mathrm{p}<0.0354$ ) greater compared to that of the control.

The mechanisms underlying the regulation of immune activation and im- 
mune exhaustion of $\mathrm{T}$ cells are unclear and regulatory $\mathrm{T}$ cells have been investigated in HIV-1 infected subjects with conflicting results [11] [12] [13] [14] [15]. In most studies, the removal of activated T CD4 cells (CD4+CD25+) from cultures of peripheral or lymphoid leukocytes from HIV+ infected patients' results in an increase in virus-specific immune responses in vitro [39] [40]. Suggesting that, Treg cells by suppressing virus-specific immunity may contribute to uncontrolled viral replication, therefore potentially playing a detrimental role in human viral infection [41]. In our study, the percentage of CD4+CD25+ T cells in the total CD4+ T cell population of the HIV+ patients was significantly higher as compared to healthy controls. Immune activation is meant to eliminate pathogens. However, sometimes activation becomes unspecific, switching something supposedly useful into damage. This double-edged sword seems especially important concerning HIV, as immune activation has been proved to be associated with disease progression [42] and might be part of the causal and not well-understood relationship between CD4 + cell loss, HIV viraemia and immune activation. In addition, we observed a decrease in the proportion of $\mathrm{CD} 4+\mathrm{CD} 25+\mathrm{T}$ cells six months after ART initiation. This could have a beneficial effect on the immune response against HIV with an advantage on the outcome of the disease. Our data suggest that $\mathrm{T}$ cell depletion is not only associated with hyperactivated $\mathrm{T}$ cells, but also an increased number of regulatory $\mathrm{T}$ cells. Indeed, the proportion of $\mathrm{CD} 4+\mathrm{CD} 25+\mathrm{FoxP} 3+$ Treg population in HIV patients that was higher at M0 decreased after 6 mouths of ART. The proportion of $\mathrm{CD} 4+\mathrm{CD} 25+\mathrm{FoxP} 3+$ Treg population at M6 tends to reach the value of controls patients.

The standard approach for monitoring treatment outcomes in patients on ART is the measurement of HIV-load over time. In our study, at baseline, significantly higher median plasma HIV-1 RNA level of 4.2 [3.2 - 5.4] copies/ml have been observed. After 6 months of ART initiation, median plasma HIV-1 RNA rapidly declined in the HIV+ patients to 2.5 [1.7 - 5.2] copies/ml. Thus, after initiation of ART, median plasma HIV-1 RNA rapidly declined in the group of HIV+ with $36.4 \%$ of patients who had HIV-1 RNA levels below the limit of detection. This decrease in viral load is a result of the effectiveness of ART in preventing the replication of HIV. Ideally, therapy initiation results in a decrease in plasma HIV-1 RNA to undetectable levels for the majority of patients. However, patients have heterogeneous immunological responses to therapy that may explain the viral load which is still detectable for the majority of patient even if the viral load are decreased [43]. In addition the baseline HIV-load level before ART initiation and treatment interruption during ART also influencing the viral load and the persistent high viral load in most cases is due to non-adherence [44].

\section{Conclusion}

Taken together, results from this study showed that ART therapy does not adversely affect the hematological indices of the study population. But we noticed 
that prevalence of anemia, leucopoenia, lymphopenia were significantly decreased after ART. Furthermore, the viral loads of participants also significantly decreased. However, serum liver enzymes ALT important for diagnosing drug induced liver toxicity showed highly significant elevated levels. Serum creatinine, a biomarker for diagnosing renal disorders, was not significantly elevated after ART. In our population, a high Treg percentage measured at ART introduction was associated with a lower CD4+. In summary, results from this study provide additional information to healthcare providers to regularly monitor hematological and biochemical indicators of HIV patients on ART, to detect and prevent toxicity early enough to improve the quality of life and reduce the risk of mortality. In a low-income setting like Burkina Faso, results from this study are important in clinical practice and patient care, given that in-depth understanding from this study will help healthcare providers to give much attention to HIV/AIDS patients taking ART. Clinicians thus must also recommend regular laboratory checks up for HIV+ patients to reduce abnormalities induced by antiretroviral drugs. The percentage of Tregs can't be used in clinical practice, but in association with CD4 nadir, can detect patients at risk for immunologic nonresponse or disorders.

\section{Funding}

This study received no funding.

\section{Author Contribution}

HSR and YT, designed the study protocol. HSR, YT and KA prepared the study tools. HSR and HYE conducted the analysis and prepared the first draft of this manuscript. HSR and SGS performed flow cytometry experiments, and analyzed the data. KE, and IPB made significant contributions to the manuscript and revised it for intellectual content. All authors read and approved the final manuscript.

\section{Acknowledgements}

The authors thank all the participants and fieldworkers who contributed their time and effort to the study, all the colleagues of the Laboratoire national de santé publique (LNSP), the Centre National de Recherche et de Formation sur le Paludisme and the Laboratoire de Biochimie et d'Immunologie Appliquée. We thank Dr. Kania Dramane from the INSP (Centre Muraz), for help during processing the Viral Load measurements; Mr. Kaboré Michael, Msc Student for his help to the data collection. We also like to acknowledge the support of the community association ALAVI who made helpful suggestions throughout the design and conduct of the research; and all representatives who facilitated the implementation of the fieldwork.

\section{Conflicts of Interest}

The authors declare no conflicts of interest regarding the publication of this paper. 


\section{References}

[1] Barré-Sinoussi, F. (1996) HIV as the Cause of AIDS. Lancet, 348, 31-35. https://doi.org/10.1016/S0140-6736(96)09058-7

[2] Simon, V., Ho, D.D. and Abdool Karim, Q. (2006) HIV/AIDS Epidemiology, Pathogenesis, Prevention, and Treatment. Lancet, 368, 489-504.

https://doi.org/10.1016/S0140-6736(06)69157-5

[3] Joint United Nations Programme on HIV/AIDS (2019) UNAIDS Fact Sheet: Global HIV Statistics, 2019. http://aidsinfo.unaids.org/

[4] Carbonneil, C., Donkova-Petrini, V., Aouba, A. and Weiss, L. (2004) Defective Dendritic Cell Function in HIV-Infected Patients Receiving Effective Highly Active Antiretroviral Therapy: Neutralization of IL-10 Production and Depletion of $\mathrm{CD} 4^{+} \mathrm{CD} 25^{+} \mathrm{T}$ Cells Restore High Levels of HIV-Specific CD4 ${ }^{+} \mathrm{T}$ Cell Responses Induced by Dendritic Cells Generated in the Presence of IFN- $\alpha$. The Journal of Immunology, 172, 7832-7840. https://doi.org/10.4049/jimmunol.172.12.7832

[5] Oxenius, A., Price, D.A., Easterbrook, P.J., O’Callaghan, C.A., Kelleher, A.D., Whelan, J.A., Sontag, G., Sewell, A.K. and Phillips, R.E. (2000) Early Highly Active Antiretroviral Therapy for Acute HIV-1 Infection Preserves Immune Function of $\mathrm{CD}^{+}$and $\mathrm{CD}^{+} \mathrm{T}$ Lymphocytes. Proceedings of the National Academy of Sciences, 97, 3382-3387. https://doi.org/10.1073/pnas.97.7.3382

[6] Murray, A.J., Kwon, K.J., Farber, D.L. and Siliciano, R.F. (2016) The Latent Reservoir for HIV-1: How Immunologic Memory and Clonal Expansion Contribute to HIV-1 Persistence. The Journal of Immunology, 197, 407-417.

https://doi.org/10.4049/jimmunol.1600343

[7] Baynes, H.W., Tegene, B., Gebremichael, M., Birhane, G., Kedir, W. and Biadgo, B. (2016) Assessment of the Effect of Antiretroviral Therapy on Renal and Liver Functions among HIV-Infected Patients: A Retrospective Study. HIVIAIDS-Research and Palliative Care, 9, 1-7. https://doi.org/10.2147/HIV.S120979

[8] Kayode, E.M., Usiegbodi, D.O., Ajboye, M.E., Omonye, I.S., Febut, M.N. and Buru, A.S. (2020) Assessment of the Effect of Anti-Retroviral Therapy on Haematological Parameters in HIV Positive Individuals in Zaria. Journal of AIDS and HIV Research, 12, 17-23.

[9] Enawgaw, B., Alem, M., Addis, Z. and Melku, M. (2014) Determination of Hematological and Immunological Parameters among HIV Positive Patients Taking Highly Active Antiretroviral Treatment and Treatment Naïve in the Antiretroviral Therapy Clinic of Gondar University Hospital, Gondar, Northwest Ethiopia: A Comparative Cross-Sectional Study. BMC Hematology, 14, Article No. 8. https://doi.org/10.1186/2052-1839-14-8

[10] López-Abente, J., Correa-Rocha, R. and Pion, M. (2016) Functional Mechanisms of Treg in the Context of HIV Infection and the Janus Face of Immune Suppression. Frontiers in immunology, 7, Article No. 192. https://doi.org/10.3389/fimmu.2016.00192

[11] Belkaid, Y. (2008) Role of Foxp3-Positive Regulatory T Cells during Infection. European Journal of Immunology, 38, 918-921. https://doi.org/10.1002/eji.200738120

[12] Gutiérrez, C., Lopez-Abente, J., Pérez-Fernández, V., Prieto-Sánchez, A., Correa-Rocha, R., Moreno-Guillen, S., Muñoz-Fernández, M. and Pion, M. (2019) Analysis of the Dysregulation between Regulatory B and T cells (Breg and Treg) in Human Immunodeficiency Virus (HIV)-Infected Patients. PLOS ONE, 14, e0213744. https://doi.org/10.1371/journal.pone.0213744

[13] Eggena, M.P., Barugahare, B., Jones, N., Okello, M., Mutalya, S., Kityo, C., Mu- 
gyenyi, P. and Cao, H. (2005) Depletion of Regulatory T Cells in HIV Infection Is Associated with Immune Activation. The Journal of Immunology, 174, 4407-4414. https://doi.org/10.4049/jimmunol.174.7.4407

[14] Saison, J., Maucort Boulch, D., Chidiac, C., Demaret, J., Malcus, C., Cotte, L., Poitevin-Later, F., Miailhes, P., Venet, F., Trabaud, M.A., Monneret, G. and Ferry, T. (2015) Increased Regulatory T-Cell Percentage Contributes to Poor CD4 ${ }^{+}$Lymphocytes Recovery: A 2-Year Prospective Study after Introduction of Antiretroviral Therapy. Open forum Infectious Diseases, 2, ofv063.

https://doi.org/10.1093/ofid/ofv063

[15] Li, G., Nunoya, J.I., Cheng, L., Reszka-Blanco, N., Tsao, L.C., Jeffrey, J. and Su, L. (2017) Regulatory T Cells Contribute to HIV-1 Reservoir Persistence in CD4 ${ }^{+} \mathrm{T}$ Cells through Cyclic Adenosine Monophosphate-Dependent Mechanisms in $\mathrm{Hu}$ manized Mice in Vivo. The Journal of Infectious Diseases, 216, 1579-1591. https://doi.org/10.1093/infdis/jix547

[16] Idigbe, E.O., Adewole, T.A., Eisen, G., Kanki, P., Odunukwe, N.N., Onwujekwe, D.I., Audu, R.A., Araoyinbo, I.D., Onyewuche, J.I., Salu, O.B., Adedoyin, J.A. and Musa, A.Z. (2005) Management of HIV-1 Infection with a Combination of Nevirapine, Stavudine, and Lamivudine: A Preliminary Report on the Nigerian Antiretroviral Program. Journal of Acquired Immune Deficiency Syndromes, 40, 65-69. https://doi.org/10.1097/01.qai.0000159516.39982.1b

[17] Roche Molecular System, Inc. (2007) COBAS $^{\star}$ AmpliPrep-COBAS $^{\circledast}$ TaqMan $^{\star}$ HIV-1-Test. https://www.fda.gov/media/73824/download

[18] Anderson, S.J., Cherutich, P., Kilonzo, N., Cremin, I., Fecht, D., Kimanga, D., Harper, M., Masha, R.L., Ngongo, P.B., Maina, W., Dybul, M. and Hallett, T.B. (2014) Maximising the Effect of Combination HIV Prevention through Prioritization of the People and Places in Greatest Need: A Modelling Study. Lancet, 384, 249-256. https://doi.org/10.1016/S0140-6736(14)61053-9

[19] Mayer, K.H. and Venkatesh, K.K. (2010) Antiretroviral Therapy as HIV Prevention: Status and Prospects. American Journal of Public Health, 100, 1867-1876. https://ajph.aphapublications.org/doi/abs/10.2105/AJPH.2009.184796

[20] Conseil National de Lutte contre le SIDA et les IST. Programme Sectoriel Santé de lutte contre le SIDA et les IST (2018) Normes et protocoles de prise en charge médicale des personnes vivant avec le VIH au Burkina Faso.

[21] Kyeyune, R., Saathoff, E., Ezeamama, A.E., Löscher, T., Fawzi, W. and Guwatudde, D. (2014) Prevalence and Correlates of Cytopenias in HIV-Infected Adults Initiating Highly Active Antiretroviral Therapy in Uganda. BMC Infectious Diseases, 14, Article No. 496. https://doi.org/10.1186/1471-2334-14-496

[22] Novitzky, N., Thomson, J., Abrahams, L., du Toit, C. and McDonald, A. (2005) Thrombotic Thrombocytopenic Purpura in Patients with Retroviral Infection Is Highly Responsive to Plasma Infusion Therapy. British Journal of Haematology, 128, 373-379. https://doi.org/10.1111/j.1365-2141.2004.05325.x

[23] Odunukwe, N., Idigbe, O., Kanki, P., Adewole, T., Onwujekwe, D., Audu, R. and Onyewuche, J. (2005) Haematological and Biochemical Response to Treatment of HIV-1 Infection with a Combination of Nevirapine + Stavudine + Lamivudine in Lagos Nigeria. Turkish Journal of Haematology, 22, 125-131.

[24] Ebonyi, A.O., Oguche, S., Ochoga, M.O., Agbaji, O.O., Anejo-Okopi, J.A., Abah, I.O., Okonkwo, P.I. and Idoko J.A. (2017) Changes in the Haematological Parameters of HIV-1 Infected Children at 6 and 12 Months of Antiretroviral Therapy in a Large Clinic Cohort North-Central Nigeria. Journal of Virus Eradication, 3, 208-211. 
https://doi.org/10.1016/S2055-6640(20)30315-0

[25] Tesfaye, Z. and Enawgaw, B. (2014) Prevalence of Anemia before and after Initiation of Highly Active Antiretroviral Therapy among HIV Positive Patients in Northwest Ethiopia: A Retrospective Study. BMC Research Notes, 7, Article No. 745. https://doi.org/10.1186/1756-0500-7-745

[26] Hawkins, T. (2010) Understanding and Managing the Adverse Effects of Antiretroviral Therapy. Antiviral Research, 85, 201-209. https://doi.org/10.1016/j.antiviral.2009.10.016

[27] Afari, S.K. and Awusah B.E. (2018) Prevalence of Haematological and Serum Biochemical Abnormalities in HIV Infected Patients in Ghana, before and after Antiretroviral Therapy. International Journal of Virology and AIDS, 5, Article No. 39. https://doi.org/10.23937/2469-567X/1510039

[28] Palella, F.J.Jr., Baker, R.K., Moorman, A.C., Chmiel, J.S., Wood, K.C. Brooks, J.T. and Holmberg, S.D. (2006) Mortality in the Highly Active Antiretroviral Therapy Era: Changing Causes of Death and Disease in the HIV Outpatient Study. Journal of Acquired Immune Deficiency Syndromes, 43, 27-34. https://doi.org/10.1097/01.qai.0000233310.90484.16

[29] Bica, I., McGovern, B., Dhar, R., Stone, D., McGowan, K., Scheib, R. and Snydman, D.R. (2001) Increasing Mortality Due to End-Stage Liver Disease in Patients with Human Immunodeficiency Virus Infection. Clinical Infectious Diseases, 32, 492-497. https://doi.org/10.1086/318501

[30] Barve, S. (2010) Focus on the Liver: Alcohol Use, Highly Active Antiretroviral Therapy, and Liver Disease in HIV-Infected. Alcohol Research \& Health, 33, 229-236.

[31] Chamroonkul, N. and Bansal, M.B. (2019) HIV and the Liver. Nature Reviews Gastroenterology \& Hepatology, 16, 1-2. https://doi.org/10.1038/s41575-018-0085-7

[32] Murphy, R.A., Sunpath, H., Kuritzkes, D.R., Venter, F. and Gandhi, R.T. (2007) Antiretroviral Therapy-Associated Toxicities in the Resource-Poor World: The Challenge of a Limited Formulary. The Journal of Infectious Diseases, 196, S449-S456. https://doi.org/10.1086/521112

[33] Pol, S., Lebray, P. and Vallet-Pichard, A. (2004) HIV Infection and Hepatic Enzyme Abnormalities: Intricacies of the Pathogenic Mechanisms. Clinical Infectious Diseases, 38, S65-S72. https://doi.org/10.1086/381499

[34] Côté, H.C., Brumme, Z.L., Craib, K.J., Alexander, C.S., Wynhoven, B., Ting, L., Wong, H., Harris, M., Harrigan, P.R., O'Shaughnessy, M.V. and Montaner, J.S. (2002) Changes in Mitochondrial DNA as a Marker of Nucleoside Toxicity in HIV-Infected Patients. The New England Journal of Medicine, 346, 811-820. https://doi.org/10.1056/NEJMoa012035

[35] Cai, J., Osikowicz, M. and Sebastiani, G. (2019) Clinical Significance of Elevated Liver Transaminases in HIV-Infected Patients. AIDS, 33, 1267-1282. https://doi.org/10.1097/QAD.0000000000002233

[36] Kalayjian, R.C., Franceschini, N., Gupta, S.K., Szczech, L.A., Mupere, E., Bosch, R.J., Smurzynski, M. and Albert, J.M. (2008) Suppression of HIV-1 Replication by Antiretroviral Therapy Improves Renal Function in Persons with Low CD4 Cell Counts and Chronic Kidney Disease. AIDS, 22, 481-487. https://doi.org/10.3390/jcm8081254

[37] Alfano, G., Cappelli, G., Fontana, F., Di Lullo, L., Di Iorio, B., Bellasi, A. and Guaraldi, G. (2019) Kidney Disease in HIV Infection. Journal of Clinical Medicine, 8, Article No. 1254. https://doi.org/10.3390/jcm8081254

[38] Kumarasamy, N., Sundaram, S., Poongulali, S., Ezhilarasi, C., Pradeep, A. and Chi- 
tra, D. (2018) Prevalence and Factors Associated with Renal Dysfunction in Patients on Tenofovir Disoproxil Fumarate-Based Antiretroviral Regimens for HIV Infection in Southern India. Journal of Virus Eradication, 4, 37-40. https://doi.org/10.1016/S2055-6640(20)30245-4

[39] Kinter, A.L., Hennessey, M., Bell, A., Kern, S., Lin, Y., Daucher, M., Planta, M., McGlaughlin, M., Jackson, R., Ziegler, S.F. and A.S. Fauci, (2004) CD25+CD4 ${ }^{+}$Regulatory T Cells from the Peripheral Blood of Asymptomatic HIV-Infected Individuals Regulate $\mathrm{CD}^{+}$and $\mathrm{CD}^{+} \mathrm{HIV}$-Specific $\mathrm{T}$ Cell Immune Responses in Vitro and Are Associated with Favorable Clinical Markers of Disease Status. The Journal of Experimental Medicine, 200, 331-343. https://doi.org/10.1084/jem.20032069

[40] Pereira, L.E., Villinger, F., Onlamoon, N., Bryan, P., Cardona, A., Pattanapanysat, K., Mori, K., Hagen, S., Picker, L. and Ansari, A.A. (2007) Simian Immunodeficiency Virus (SIV) Infection Influences the Level and Function of Regulatory T Cells in SIV-Infected Rhesus Macaques But Not SIV-Infected Sooty Mangabeys. Journal of virology, 81, 4445-4456. https://doi.org/10.1128/JVI.00026-07

[41] Bolacchi, F., Sinistro, A., Ciaprini, C., Demin, F., Capozzi, M., Carducci, F.C., Drapeau, C.M., Rocchi, G. and Bergamini, A. (2006) Increased Hepatitis C Virus (HCV)-Specific CD $4^{+} \mathrm{CD} 25^{+}$Regulatory T Lymphocytes and Reduced HCV-Specific $\mathrm{CD}^{+}{ }^{+} \mathrm{T}$ Cell Response in HCV-Infected Patients with Normal versus Abnormal Alanine Aminotransferase Levels. Clinical and Experimental Immunology, 144, 188-196. https://doi.org/10.1111/j.1365-2249.2006.03048.x

[42] Boasso, A., Shearer, G.M. and Chougnet, C. (2008) Immune Dysregulation in Human Immunodeficiency Virus Infection: Know It, Fix It, Prevent It? Journal of Internal Medicine, 265, 78-96. https://doi.org/10.1111/j.1365-2796.2008.02043.x

[43] Edwards, J.K., Cole, S.R., Martin, J.N., Moore, R., Mathews, W.C., Kitahata, M., Eron, J.J., Saag, M. and Mugavero, M.J. (2015) Dynamic Visual Display of Treatment Response in HIV-Infected Adults. Clinical Infectious Diseases, 61, e1-e4. https://doi.org/10.1093/cid/civ262

[44] Chendi, B.H., Okomo Assoumou, M.C., Jacobs, G.B., Yekwa, E.L., Lyonga, E., Mesembe, M., Eyoh, A. and Ikomey, G.M. (2019) Rate of Viral Load Change and Adherence of HIV Adult Patients Treated with Efavirenz or Nevirapine Antiretroviral Regimens at 24 and 48 Weeks in Yaoundé, Cameroon: A Longitudinal Cohort Study. BMC Infectious Diseases, 19, Article No. 194.

https://doi.org/10.1186/s12879-019-3824-7 